\title{
MORPHOLEXICAL PROPERTIES OF ENGLISH AND SLOVENIAN MASCULINE/FEMININE NOUNS FOR PROFESSIONS
}

\author{
Gašper Ilc \\ Andrej Stopar \\ Faculty of Arts \\ University of Ljubljana \\ Ljubljana, Slovenia
}

Key words: associative meaning, collocators, corpus frequency, feminatives, masculinatives, word-formation, semantic preference.

Summary: The article presents an analysis of masculine and feminine nouns denoting professions in English and Slovenian. The researched expressions are first discussed from the point of view of word-formation (derivation and compounding), then corpora are employed to examine the frequency of the forms in both languages. The corpus data are complemented with an analysis of collocators with the purpose of identifying the semantic preferences and associative meanings of gender-marked expressions for professions. The results reveal that some feminine nouns for professions are stylistically unmarked (especially in Slovenian), whereas others cooccur (in English and Slovenian) with words that reflect the societal attitudes to gender roles, appearance and character.

\section{MORFO-LEKSIKALNE ZNAČILNOSTI ANGLEŠKIH IN SLOVENSKIH MOŠKIH/ŽENSKIH SAMOSTALNIKOV ZA POKLICE}


Ključne besede: asociativni pomen, feminativi, kolokatorji, maskulinativi, oblikotvorje, pogostnost v korpusu, semantična preferenca.

Povzetek: Članek predstavi kontrastivno analizo moških in ženskih samostalnikov za poklice na jezikovnem paru angleščina-slovenščina. Obravnavani izrazi so najprej predstavljeni z besedotvornega vidika, prek izpeljave oziroma zlaganja. Prispevek nato $\mathrm{s}$ pomočjo korpusov preverja pogostnost opazovanih oblik $\mathrm{v}$ obeh jezikih. Zbrane korpusne podatke razčleni tudi s pregledom njihovih kolokatorjev, s čimer opredeli semantične preference in pomenske asociacije obravnavanih feminativov in maskulinativov. Rezultati pokažejo, da so feminativi za poklice lahko nezaznamovani (sploh v slovenščini) ali pa se pojavljajo z izrazi, ki (v angleščini in v slovenščini) odsevajo družbeni odnos do spolnih vlog, videza in osebnostnih lastnosti.

\section{Introduction}

It is well-known that several distinct levels of (un)markedness can be observed with nouns specifically denoting male or/and female referents. Starting with morphology, morphologically marked nouns for gender involve (un)markedness in terms of the (non-)presence of special genderrelated morphology, be it inflectional or derivational. In English, for example, the noun actor is morphologically unmarked as it lacks any gender-related morphological markings, whereas the gender-related morpheme -ess in actress makes the female-referring noun marked. Exactly the same can be observed for their Slovenian counterparts igralec (masculine noun, male or female referents, morphologically unmarked) and igralka (feminine noun, female referents, morphologically marked) ${ }^{1}$. At the level of semantics, it has traditionally been assumed that in a pair of masculine/feminine nouns (e.g., actor/actress), the masculine noun is unmarked as it can denote both female and male referents, whereas the feminine noun is marked, allowing only the denotation of female referents (cf. Huddleston in Pullum, 2002: 1680ff; Toporišič, 2000: 266; VidovičMuha, 2018). The current usage, however, shows that the unmarkedness of masculine nouns for both genders is disputable (Kranjc in Ožbot, 2013: 234). The reason for this development can lie in the fact that it is often the

\footnotetext{
${ }^{1}$ This is a slight oversimplification. Both nouns are derived from the verbal base igral-, and then the derivational morpheme $-e c$ is added for the masculine noun, and $-k a$ for the feminine noun (cf. Vidovič-Muha, 2018: 410). The morpheme -ec carries no overt masculine marker, but this is the case of masculine nouns of the 1st declension, whereas the morpheme - $k a$ carries the overt feminine marker $a$, typical of feminine nouns of the 1st declension (cf. VidovičMuha, 2018: 415).
} 
case that the feminine noun has acquired some negative connotations through usage, so the users prefer the non-connotative masculine noun instead (e.g., poet/poetess, master/mistress). This observation leads us to the third type of markedness, stylistic, which is the focus of the present paper. In particular, the paper addresses the question of the stylistic (un)markedness of English and Slovenian gender-marked expressions for professions (henceforth: masculine/feminine nouns), analysing the data from different referential corpora: BNC, English web corpus 2013 (enTenTen13), and the Brown Family of English, and FidaPLUS v2 for Slovenian.

The corpus-based approach adopted herein examines gender-marked expressions for professions in their typical (co-)texts. The data on the cooccurrence of lexical units in corpora are used to analyse various aspects of their use. In line with Sinclair (1996), our choice of units of meaning depends on their linguistic co-text - his term 'extended units of meaning' thus takes into account the attractions between the word and its typical environments, which are based on collocation, colligation, semantic preference and semantic prosody.

Collocations are frequent co-occurrences of lexical units; Stubbs (2001) exemplifies such combinations with the phrase rancid butter. Gabrovšek (2005: 210-12) points out that collocations can be either semantically or lexically motivated - a semantically acceptable combination may still be unacceptable with regard to the frequency of its use (compare * glacial age and ice age). More recent definitions of collocations consider several properties of collocations to define them as "lexically and pragmatically constrained recurrent cooccurrences of at least two lexical items which are in a direct syntactic relation with each other" (Bartsch, 2004: 76). A colligation, on the other hand, refers to the frequent co-occurrences of words based on the syntactic patterns that include, for instance, negation, mood, person, number, tense, and quantifiers. For example, the verb deny requires a gerund, whereas the verb decline requires an infinitive: He denied visiting him. vs. He declined to visit him.

Corpora enable us to determine the discursive (or lexical/semantic) fields typical for a unit of meaning (Stubbs, 2007: 178; McIntyre, 2018: 87). The noun saucer, for example, is frequently found next to teapot, teacup, plate, and drop, but also next to flying (BNC via Sketch Engine, 2019). Saucer thus often appears in texts that describe tea drinking, setting the table, and similar; however, the same word is also frequent in texts related to unknown flying objects. In some cases, these word combinations can be classified as proper collocations (matching saucers), while in others they do not correspond to our initial definition of collocations. Such an example can 
be seen in the clause to stack the dirty cups and saucers on the tray: here the nouns saucers and tray do not represent a collocation, but rather exhibit a tendency to appear in the same text. Stubbs (2001) presents a similar case by discussing the co-occurrence of large and various words denoting quantity (number, amount, scale). Gabrovšek $(2005,211)$ explains that such combinations have been classified by Crowther, Dignen and Lea (2002) as examples of categorial collocations - frequent co-occurrences within the discursive field. The latter are also closely related to the term semantic preference (Stubbs, 2001 and 2007), which is the tendency of the word to co-occur with words that belong to the same semantic set. Philip (2010) claims that semantic preference is shared by all speakers of a language.

Closely related to semantic preference is Hoey's (2005) associative meaning, which focuses on the wider context and on the process of learning a word that includes acquiring its referential meaning, syntactic environments, connotations, and associations. Speakers expect the lexical unit to behave in a certain way and associate it with a set of meanings that (may) entail its collocates (Hoey, 2005: 26). The difference between Hoey's associative meaning and Sinclair's semantic preference is in that the former also entails the secondary meanings of associations, evaluations and connotations. Philip (2010) describes this as a psychological aspect of understanding the lexical unit which is not necessarily shared by all speakers. For instance, the frequent use of adjectives describing appearance (beautiful) when discussing women, and the use of adjectives expressing importance (leading) when discussing men may reflect value judgments with potential societal ramifications (Caldas-Coulthard and Moon, 2010).

When the semantic aspects of lexical units are assigned a pragmatic function, semantic prosody comes into play (Philip, 2010). McIntyre (2018: 87-88) explains that, according to Sinclair, "semantic prosody describes the discourse function of the unit of meaning" and emphasizes that semantic prosodies "belong to units of meaning and not to individual words". He discusses the nouns job and career and shows that they both convey a similar semantic preference, yet corpus hits show that the typical collocates of career more often express a positive semantic prosody. In this respect semantic prosody refers to the positive and negative associations acquired by neutral words when they co-occur with other words (Šorli, 2012 and 2013; Gabrovšek, 2014; Jurko, 2015).

The sections that follow use the extended units of meanings - especially semantic preference and associative meaning - to analyse the corpus data for masculine/feminine nouns for professions. 


\section{Gender-marked nouns for professions: basic theoretical tenets}

With a few exceptions (see below), English allows only so-called notional or semantic gender, meaning that the noun acquires its gender through reference with a real person (cf. Quirk et al., 1999: 314; Huddleston and Pullum, 2002: 484). For instance, the noun teacher is morphologically unmarked for gender, and displays semantic gender agreement with its referent (1a-b). When there is no referent (i.e., generic reference), the noun can refer to either male or female referents or both (1c).

(1) a) She was a very popular teacher because of her personal interest in them.

b) I'm not sure what my dad does. I think he is a teacher in the Air Force.

c) This is a first-level administrative post within an education department, usually for an experienced teacher. He or she works under an assistant education officer ${ }^{2}$.

In some cases, English has special forms to distinguish masculine/feminine nouns. These can be morphologically unmarked pairs (e.g., boy/girl, fox/vixen), or morphologically marked pairs ${ }^{3}$. The feminine nouns are derived either by the gender-marking morphemes -ess, -ette, -ine, -trix, or by compounding with the component elements she, woman, whereas the masculine nouns by the gender-marking morpheme -er, or the gender-marking component elements he and man (cf. Quirk et al., 1999: 1546f.; Huddleston in Pullum, 2002: 1680ff.; Bauer, 1996: 220f.).

For everyday usage, it is advisable (cf. Huddleston in Pullum, 2002: 1680) to avoid using morphologically marked feminine nouns unless their use is semantically or pragmatically motivated. For instance, the difference between a count and a countess or an abbot and an abbess is not just gender-related but also semantic, as they refer to differ societal and legal positions. In a similar fashion, the use of the feminine nouns actress and waitress is justified, as they also denote different theatre roles and job specifics respectively. Another reason for using a morphologically marked feminine noun is contextual: he married a rich heiress is not the same as he married a rich heir (Huddleston in Pullum, ibid.).

The main reason for avoiding some feminine nouns may lie in the fact that diachronically these nouns acquired negative connotative meanings and

\footnotetext{
${ }^{2}$ All the examples listed in the paper are taken from the following corpora: BNC and English Web 2013 for English and FidaPLUS v2 for Slovenian.

${ }^{3}$ There is also a third group of nouns, whereby the gender is fully grammaticalized and involves the personification of inanimate nouns (e.g., states, vehicles, emotions, etc.).
} 
are consequently felt as pejorative in present-day usage (cf. Holmes, 2001: 126). Thus, derivates such as poetess, authoress and editorette, are of rare occurrences (see Table 1).

Table 1. poetess, authoress and editorette vs. poet, author and editor

\begin{tabular}{|l|l|l|l|l|l|l|l|l|l|}
\hline query & \multicolumn{2}{|c|}{ BNC } & \multicolumn{2}{|c|}{ enTenTen13 } & \multicolumn{3}{|l|}{ BNC } & \multicolumn{2}{l|}{ enTenTen13 } \\
\hline & No. & $\begin{array}{l}\text { per } \\
\mathrm{M}^{4}\end{array}$ & No. & per M & & No. & per M & No. & per M \\
\hline poetess & 25 & 0.22 & 1762 & 0.08 & poet & 2917 & 25.96 & 334032 & 14.7 \\
\hline authoress & 23 & 0.20 & 1089 & 0.05 & author & 6809 & 60.61 & 2726767 & 120.0 \\
\hline editorette & 0 & 0 & 1 & 0 & editor & 5440 & 48.42 & 1316870 & 57.9 \\
\hline
\end{tabular}

In contrast to English, in Slovenian, gender is fully grammaticalized, meaning that the gender of a noun can either be the same of different from the gender of the referent. As a rule, the noun preserves its gender regardless of its referent (2a). There are, however, some exceptions. Some nouns such as starešina ('a chief') and vodja ('a leader') $)^{5}$ can be either feminine or masculine depending on the referent $(2 b, c)$ due to their morphological make-up (cf.: Uhlik, 2019).

(2) a) Ona je dober/*dobra pedagog.

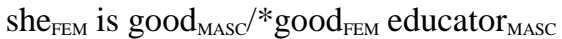

'She is a good educator.'

b) Kot skrben vodja je priljubljen pri delavcih.

as attentive MASC $_{\text {leader }}$ MASC is popular MASC $_{\text {at }}$ at workers

'Being attentive, he is very popular among the workers.'

c) Vodja je prisluhnila našim željam.

leader $_{\mathrm{FEM}}$ is listened $\mathrm{F}_{\mathrm{FEM}}$ our wishes.

'The leader listened to our wishes.'

When analysing feminine derivatives, Vidovič-Muha (2018: 408) identifies the suffixes - $a$, -(ar)ka, -esa, -ica, -ina, -inja, -isa, -ja, -ka, (ov)ka, -na and -ulja, with the following productive suffixes: -(ar)ka, -ica, and -inja. With regard to the suffixes used to derive nouns denoting male professions, the author (Vidovič-Muha, 2018: 410) discusses the suffix -ec. In her paper on designators for female holders of professions in Slovenian and Russian, Derganc (2017: 23f) argues that those in Slovenian are

\footnotetext{
${ }^{4}$ Per million words.

${ }^{5}$ Vodja can denote both male and female referents; however, its derivatives računovodja ('an accountant') and poslovodja ('a manager') have feminine derivatives ending in -inja: računovodkinja and poslovodkinja, respectively.
} 
stylistically unmarked. It is noteworthy that the corpus data show that in most cases the masculine nouns are much more numerous than their feminine counterparts (cf. Štumberger 2015). As already pointed out by Derganc (2017: 126), this is an expected observation, since, first, in the past the masculine nouns were used generically, and, second, the most prestigious positions and jobs were occupied by men. In addition to these two factors, special attention also has to be paid to the social context (cf. Vidovič-Muha, 2018: 413). For example, in Table 2, high values for the masculine noun zdravnik ('a doctor') can be attributed to the generic use, whereas the high values for the feminine nouns sobarica ('a chambermaid'), vzgojiteljica ('a kindergarten teacher'), and the masculine noun varilec ('a welder') result from the fact that these are the professions typically practised by females or males.

Table 2. Frequency of selected masculine/feminine nouns for professions in FidaPLUS $v 2$

\begin{tabular}{|l|l|l|l|}
\hline & No. & & No. \\
\hline zdravnik & 34775 & zdravnica & 4811 \\
\hline učitelj & 17842 & učiteljica & 8782 \\
\hline sobar & 111 & sobarica & 414 \\
\hline vzgojitelj & 4965 & vzgojiteljica & 6535 \\
\hline varilec & 418 & varilka & 9 \\
\hline
\end{tabular}

\section{Methodology}

For the purposes of the analysis, we first extracted all English feminine nouns for professions from the British National Corpus, BNC, (100 million words, from 1960-1993, written and spoken discourse) in line with the morphological specifications presented in section 2 . The final list after the extraction contains 39 feminine nouns for professions derived by the suffixes -ess, -trix and the component element woman. To determine the frequency of feminine nouns in English, the data from the BNC were compared with the data obtained from the English web corpus 2013, enTenTen13, (19 billion words, written language from the uk web sites from 2013). The data from the Brown Family corpora (American and British English, divided into four subcorpora at 30-year intervals - 1931, 1961, 1991 and 2006) were used to examine the frequency and the usage tendencies from a diachronic perspective.

The basis for the analysis of Slovenian feminine nouns was the database by the Employment Service of Slovenia, available online at: https://www.ess.gov.si/ncips/opisi-poklicev. The database contains 
masculine nouns only, so the next step was to check the existence of corresponding feminine nouns in the Dictionary of Standard Slovenian $\left(\mathrm{SSKJ}^{2}\right.$ available at: fran.si), and in the FidaPLUS v2 corpus. The final list after the extraction contains 289 feminine nouns for professions derived by the suffixes -esa, -ica, -inja and -(ar)ka.

Stylistic (un)markedness was ascertained with the help of the collocation candidate tool provided by the Sketch Engine interface. For each investigated noun, collocation candidates were sought in the span from -5 to +5 words, and then the $\log$ Dice measurement was examined. According to Rychlý (2008), the logDice highest value is 14, with the value of 7 and above indicative of collocational association (cf. Gablasova et al., 2017: 168f).

The analysis of extended units of meaning is based on Word Sketch, a feature of Sketch Engine that provides a summary of a word's grammatical and collocational behaviour (Kilgarriff et al., 2014). The data collected in this way enabled the study of stylistic (un)markedness based on the concepts of semantic preference and associative meaning (Sinclair, 1996; Hoey, 2005; Philip, 2010).

\section{Results}

\subsection{Corpus frequencies}

In English, the highest proportion of feminine nouns for professions is derived by the suffix -ess (21), followed by the compounds with woman (15). Only one noun ending in -ette was identified (usherette), and two nouns ending in -atrix (aviatrix and prosecutrix). In Table 3, we present those feminine nouns that were found at least 200 times in the enTenTen 13 corpus. It should be noted that due to the different sizes of the enTenTen 13 and BNC corpora, only a value per million words is comparable. The data from the Brown Family subcorpora is comparable in terms of raw frequency, since all subcorpora contain the same number of words.

Table 3. Frequency of feminine nouns in English

\begin{tabular}{|c|c|c|c|c|c|c|c|c|}
\hline \multirow[t]{2}{*}{ feminine noun } & \multicolumn{2}{|c|}{ enTenTen13 } & \multicolumn{2}{|c|}{ BNC } & \multicolumn{4}{|c|}{ Brown Family } \\
\hline & & & & & 1931 & 1961 & 1991 & 2006 \\
\hline & No. & per $\mathrm{M}$ & No. & per $\mathrm{M}$ & No. & No. & No. & No. \\
\hline actress & 310864 & 13.70 & 1259 & 11.21 & 18 & 25 & 61 & 38 \\
\hline mistress & 132414 & 5.80 & 1179 & 3.45 & 25 & 32 & 22 & 39 \\
\hline waitress & 73030 & 3.20 & 361 & 3.21 & 3 & 8 & 14 & 13 \\
\hline hostess & 59524 & 2.60 & 422 & 3.76 & 11 & 31 & 20 & 10 \\
\hline
\end{tabular}




\begin{tabular}{|l|r|r|r|r|r|r|r|r|}
\hline stewardess & 13665 & 0.47 & 97 & 0.86 & 4 & 3 & 9 & 7 \\
\hline headmistress & 6243 & 0.27 & 255 & 2.26 & 1 & 6 & 0 & 0 \\
\hline huntress & 6218 & 0.27 & 7 & 0.06 & 0 & 1 & 0 & 0 \\
\hline saleswoman & 3842 & 0.17 & 22 & 0.20 & 0 & 0 & 0 & 3 \\
\hline policewoman & 3834 & 0.17 & 228 & 2.03 & 0 & 3 & 0 & 2 \\
\hline laundress & 1818 & 0.08 & 13 & 0.12 & 0 & 0 & 1 & 0 \\
\hline washerwoman & 958 & 0.04 & 22 & 0.20 & 1 & 0 & 0 & 0 \\
\hline anchorwoman & 897 & 0.04 & 2 & 0.02 & 0 & 0 & 0 & 0 \\
\hline manageress & 803 & 0.04 & 104 & 0.93 & 0 & 1 & 1 & 0 \\
\hline schoolmistress & 789 & 0.03 & 26 & 0.24 & 2 & 0 & 0 & 0 \\
\hline sculptress & 726 & 0.03 & 11 & 0.10 & 0 & 0 & 0 & 0 \\
\hline usherette & 629 & 0.03 & 28 & 0.25 & 0 & 0 & 0 & 0 \\
\hline aviatrix & 535 & 0.02 & 1 & 0.01 & 0 & 0 & 0 & 0 \\
\hline directress & 529 & 0.02 & 1 & 0.01 & 0 & 0 & 0 & 0 \\
\hline fisherwoman & 509 & 0.02 & 2 & 0.02 & 0 & 0 & 0 & 0 \\
\hline instructuress & 347 & 0.02 & 6 & 0.05 & 1 & 0 & 0 & 0 \\
\hline ambassadress & 297 & 0.01 & 1 & 0.01 & 0 & 0 & 0 & 0 \\
\hline conductress & 202 & 0.01 & 12 & 0.11 & 0 & 0 & 0 & 0 \\
\hline
\end{tabular}

The corpus data in Table 3 shows that the most commonly used feminine nouns for professions in English are the nouns actress and waitress, but the data from the Brown Family reveal that there was a decrease between 1991 and 2006 in the use of the noun actress. With all other feminine nouns ending in -ess, there is a decrease in usage. Special attention must be paid to the nouns mistress and huntress. The data in Table 3 suggest more frequent values in the enTenTen 13 corpus then in others; however, we believe that the increase should not be attributed to the more frequent use of the two nouns when denoting female professionals. The noun mistress is polysemous as it may also denote a female lover. A better insight into the actual use of the noun mistress when denoting female professionals can thus be observed in the case of the compounds headmistress and schoolmistress: in both cases there is a sharp decrease in usage. The noun huntress, on the other hand, can also denote characters in computer games and films, so for this reason the occurrence of huntress is relatively high in the enTenTen 13 corpus. There is a slight increase in the 
use of some compounds with woman (e.g., anchorwoman, saleswoman); however, in some other cases, the usage is on the decrease (e.g., policewoman).

In Slovenian, the majority of feminine nouns denoting professions are derived by the suffix -(ar)ka (190), to be followed by the suffixes -ica and inja (each around 50). Only two nouns with the suffix -esa were identified: klovnesa ('a clown') and stevardesa ('a stewardess'). In some cases, it may seem that the feminine nouns for the same profession may be derived by two different suffixes, for example, mesarica and mesarka. However, mesarica ('the butcher's wife'), according to the SSKJ ${ }^{2}$, does not denote a profession but a social position of a woman (cf. Vidovič-Muha, 2018: 408), whereas the noun mesarka ('a butcher') pertains to the profession, and has as such also been standardised in the National Qualifications Framework (SOK). The $\mathrm{SSKJ}^{2}$ defines the noun kovačica in a similar fashion as mesarica ('the blacksmith's wife'), but the SOK uses the same word for a female profession (i.e., 'a female blacksmith'). The masculine noun geograf ('a geographer') has two feminine counterparts geografka and geografinja, with only the latter being standardised in the SOK. In addition to female nouns, our analysis has identified the morpheme -ar, which is used to derive masculine nouns from feminine nouns (e.g., babičar 'a male midwife').

Table 4 shows those feminine nouns that have at least 200 occurrences in the FidaPLUS v2. The data are provided separately for the 1979-1990 and 200-2006 subcorpora. Due to different sizes of the subcorpora only the value per million words is comparable ${ }^{6}$.

Table 4. Frequency of feminine nouns in Slovenian

\begin{tabular}{|c|c|c|c|c|c|c|c|c|c|c|c|}
\hline \multirow[t]{2}{*}{ feminine noun } & \multicolumn{2}{|c|}{$\begin{array}{l}\text { subcorpus } \\
1979-1990\end{array}$} & \multicolumn{2}{|c|}{$\begin{array}{l}\text { subcorpus } \\
2000-2006 \\
\end{array}$} & \multirow{2}{*}{$\begin{array}{l}\text { total } \\
\text { No. }\end{array}$} & \multirow[t]{2}{*}{ feminine noun } & \multicolumn{2}{|c|}{$\begin{array}{l}\text { subcorpus } \\
1979-1990 \\
\end{array}$} & \multicolumn{2}{|c|}{$\begin{array}{l}\text { subcorpus } \\
2000-2006 \\
\end{array}$} & \multirow{2}{*}{$\begin{array}{l}\text { total } \\
\text { No. }\end{array}$} \\
\hline & No. & Per M & No. & per M & & & No. & per M & No. & per M & \\
\hline igralka & 9,091 & 45.00 & 37,246 & 72.00 & 46,337 & sobarica & 248 & 1.23 & 774 & 1.49 & 1,022 \\
\hline direktorica & 6,724 & 33.00 & 25,340 & 49.00 & 32,064 & gasilka & 279 & 1.00 & 724 & 1.00 & 1,003 \\
\hline babica & 4,916 & 24.00 & 15,374 & 30.00 & 20,290 & izvajalka & 203 & 1.00 & 796 & 2.00 & 999 \\
\hline učiteljica & 4,628 & 23.00 & 11,924 & 22.90 & 16,552 & fotografinja & 152 & 1.00 & 817 & 2.00 & 969 \\
\hline delavka & 3,931 & 20.00 & 10,066 & 19.00 & 13,997 & ekonomistka & 264 & 1.00 & 695 & 1.00 & 959 \\
\hline novinarka & 3,242 & 16.00 & 9,458 & 18.00 & 12,700 & varuhinja & 203 & 1.01 & 740 & 1.42 & 943 \\
\hline sodnica & 2,488 & 12.40 & 9,385 & 18.02 & 11,873 & kozmetičarka & 149 & 1.00 & 775 & 1.00 & 924 \\
\hline
\end{tabular}

\footnotetext{
${ }^{6}$ Table 4 also lists nouns babica, detektivka, kuharica, lovka and spremljevalka, even though these are polysemous items: babica ('a midwife' or 'a grandmother'), detektivka ('a female detective' or 'a detective book/film'), kuharica ('a female cook', or 'a cookery book'), lovka ('a female hunter' or 'a tentacle'), and spremljevalka ('a companion' or 'a runner-up in a beauty competition').
} 


\begin{tabular}{|c|c|c|c|c|c|c|c|c|c|c|c|}
\hline sekretarka & 3,644 & 18.10 & 8,183 & 15.71 & $\mathbf{1 1 , 8 2 7}$ & stilistka & 25 & 0.12 & 874 & 1.68 & 899 \\
\hline tajnica & 3,448 & 17.20 & 7,424 & 14.30 & 10,872 & menedžerka & 132 & 1.00 & 742 & 1.00 & 874 \\
\hline ravnateljica & 2,647 & 13.17 & 6,692 & 12.85 & 9,339 & negovalka & 170 & 1.00 & 681 & 1.00 & 851 \\
\hline svetovalka & 2,200 & 10.94 & 5,892 & 11.30 & 8,092 & predavateljica & 167 & 0.83 & 674 & 1.29 & 841 \\
\hline poslanka & 3,077 & 45.31 & 4,726 & 9.07 & 7,803 & zastopnica & 247 & 1.23 & 572 & 1.10 & 819 \\
\hline zdravnica & 1,818 & 9.04 & 5,922 & 11.37 & 7,740 & opazovalka & 258 & 1.28 & 554 & 1.06 & 812 \\
\hline manekenka & 1,392 & 7.00 & 5,986 & 11.00 & 7,378 & vodnica & 178 & 0.89 & 630 & 1.21 & 808 \\
\hline plesalka & 1,412 & 7.02 & 5,929 & 11.40 & 7,341 & referentka & 217 & 1.08 & 589 & 1.13 & 806 \\
\hline prodajalka & 1,735 & 8.63 & 5,562 & 10.68 & 7,297 & lektorica & 211 & 1.00 & 583 & 1.00 & 794 \\
\hline vzgojiteljica & 2,013 & 10.01 & 4,488 & 8.62 & 6,501 & napovedovalka & 219 & 1.00 & 569 & 1.00 & 788 \\
\hline voznica & 1,215 & 6.04 & 4,789 & 9.19 & 6,004 & uradnica & 230 & 1.14 & 530 & 1.02 & 760 \\
\hline pomočnica & 1,204 & 5.99 & 3,956 & 7.59 & 5,160 & računovodkinja & 207 & 1.03 & 517 & 0.99 & 724 \\
\hline natakarica & 1,417 & 7.00 & 3,383 & 6.00 & 4,800 & etnologinja & 243 & 1.00 & 456 & 1.00 & 699 \\
\hline spremljevalka & 1,038 & 5.16 & 3,663 & 7.03 & 4,701 & vojakinja & 121 & 0.60 & 578 & 1.11 & 699 \\
\hline režiserka & 804 & 4.00 & 3,613 & 6.94 & 4,417 & dirigentka & 117 & 1.00 & 536 & 1.00 & 653 \\
\hline športnica & 936 & 4.66 & 3,211 & 6.16 & 4,147 & terapevtka & 117 & 0.58 & 530 & 1.02 & 647 \\
\hline kuharica & 999 & 5.00 & 2,866 & 6.00 & 3,865 & sociologinja & 188 & 0.94 & 440 & 0.84 & 628 \\
\hline tehnica & 240 & 1.19 & 3,430 & 6.58 & 3,670 & fizioterapevtka & 148 & 1.00 & 476 & 1.00 & 624 \\
\hline odvetnica & 677 & 3.37 & 2,334 & 4.48 & 3,011 & bolničarka & 186 & 1.00 & 428 & 1.00 & 614 \\
\hline oblikovalka & 526 & 2.62 & 2,454 & 4.71 & 2,980 & inženirka & 177 & 1.00 & 435 & 1.00 & 612 \\
\hline šivilja & 714 & 3.55 & 1,928 & 3.70 & 2,642 & pediatrinja & 109 & 0.54 & 484 & 0.93 & 593 \\
\hline psihologinja & 590 & 2.93 & 1,872 & 3.59 & 2,462 & upravnica & 152 & 0.76 & 391 & 0.75 & 543 \\
\hline izvedenka & 529 & 3.00 & 1,875 & 4.00 & 2,404 & scenaristka & 87 & 0.43 & 438 & 0.84 & 525 \\
\hline prometnica & 661 & 3.29 & 1,595 & 3.06 & 2,256 & maserka & 103 & 1.00 & 404 & 1.00 & $\mathbf{5 0 7}$ \\
\hline strokovnjakinja & 440 & 2.19 & 1,790 & 3.44 & 2,230 & biologinja & 114 & 1.00 & 384 & 1.00 & 498 \\
\hline prevajalka & 502 & 2.50 & 1,680 & 3.23 & 2,182 & posrednica & 133 & 0.66 & 361 & 0.69 & 494 \\
\hline inšpektorica & 522 & 3.00 & 1,616 & 3.00 & 2,138 & receptorka & 155 & 0.77 & 334 & 0.64 & 489 \\
\hline pedagoginja & 546 & 2.72 & 1,461 & 2.80 & 2,007 & oskrbnica & 113 & 0.56 & 363 & 0.70 & 476 \\
\hline asistentka & 326 & 2.00 & 1,612 & 3.00 & 1,938 & poslovodkinja & 134 & 0.67 & 319 & 0.61 & 453 \\
\hline čistilka & 472 & 2.00 & 1,461 & 3.00 & 1,933 & vizažistka & 8 & 0.04 & 434 & 0.83 & 442 \\
\hline mojstrica & 359 & 2.00 & 1,396 & 3.00 & 1,755 & strežnica & 154 & 0.77 & 276 & 0.53 & 430 \\
\hline glasbenica & 326 & 2.00 & 1,393 & 3.00 & 1,719 & zobozdravnica & 140 & 0.70 & 286 & 0.55 & 426 \\
\hline trenerka & 361 & 1.80 & 1,338 & 2.57 & 1,699 & kostumografinja & 92 & 0.01 & 309 & 1.00 & 401 \\
\hline stevardesa & 287 & 1.43 & 1,384 & 2.66 & 1,671 & cvetličarka & 83 & 0.01 & 304 & 1.00 & 387 \\
\hline veleposlanica & 640 & 3.18 & 1,015 & 1.95 & 1,655 & arheologinja & 96 & 0.01 & 287 & 1.00 & 383 \\
\hline lovka & 424 & 2.00 & 1,211 & 2.00 & 1,635 & točajka & 133 & 0.66 & 231 & 0.44 & 364 \\
\hline
\end{tabular}




\begin{tabular}{|l|c|c|c|c|c|l|c|c|c|c|c|}
\hline kustosinja & 345 & 2.00 & 1,272 & 2.00 & $\mathbf{1 , 6 1 7}$ & izdelovalka & 91 & 0.01 & 266 & 1.00 & $\mathbf{3 5 7}$ \\
\hline frizerka & 287 & 1.00 & 1,327 & 3.00 & $\mathbf{1 , 6 1 4}$ & antropologinja & 61 & 0.01 & 293 & 1.00 & $\mathbf{3 5 4}$ \\
\hline policistka & 336 & 1.67 & 1,253 & 2.41 & $\mathbf{1 , 5 8 9}$ & klovnesa & 43 & 0.01 & 310 & 1.00 & $\mathbf{3 5 3}$ \\
\hline organizatorka & 306 & 1.52 & 1,212 & 2.33 & $\mathbf{1 , 5 1 8}$ & veterinarka & 78 & 0.39 & 269 & 0.52 & $\mathbf{3 4 7}$ \\
\hline $\begin{array}{l}\text { arhitektka } \\
\text { pravnica }\end{array}$ & 290 & 1.00 & 1,225 & 2.00 & $\mathbf{1 , 5 1 5}$ & administratorka & 112 & 1.00 & 233 & 0.10 & $\mathbf{3 4 5}$ \\
\hline $\begin{array}{l}\text { koreografinja } \\
\text { zgodovinarka }\end{array}$ & 392 & 1.95 & 1,037 & 1.99 & $\mathbf{1 , 4 2 9}$ & notarka & 62 & 0.01 & 270 & 1.00 & $\mathbf{3 3 2}$ \\
\hline solistka & 330 & 1.64 & 1,027 & 1.97 & $\mathbf{1 , 3 5 7}$ & telefonistka & 103 & 0.51 & 181 & 0.35 & $\mathbf{2 8 4}$ \\
\hline blagajničarka & 305 & 2.00 & 1,042 & 2.00 & $\mathbf{1 , 3 4 7}$ & farmacevtka & 42 & 0.01 & 211 & 0.01 & $\mathbf{2 5 3}$ \\
\hline detektivka & 204 & 1.00 & 1,049 & 2.00 & $\mathbf{1 , 2 5 3}$ & mlinarica & 108 & 1.00 & 125 & 0.01 & $\mathbf{2 3 3}$ \\
\hline $\begin{array}{l}\text { knjižničarka } \\
\text { dramaturginja }\end{array}$ & 321 & 2.00 & 923 & 2.00 & $\mathbf{1 , 2 4 4}$ & oskrbovalka & 6 & 0.03 & 223 & 0.43 & $\mathbf{2 2 9}$ \\
\hline $\begin{array}{l}\text { upraviteljica } \\
\text { kiparka }\end{array}$ & 275 & 1.37 & 816 & 1.57 & $\mathbf{1 , 0 9 1}$ & matičarka & 31 & 0.01 & 185 & 0.01 & $\mathbf{2 1}$ \\
\hline
\end{tabular}

Comparing the data from both suborpora, we can observe that the number of feminine nouns for professionals is either on the increase (e.g., igralka ('an actress'), novinarka ('a journalist'), režiserka ('a film director')) or it maintains its value over time (e.g., delavka ('a worker'), zgodovinarka ('a historian'), solistka ('a soloist')). There are only few examples where a decrease has been observed (e.g., sekretarka ('a secretary'), telefonistka ('a telephonist')). The reason for such declines could be that these professions are slowly disappearing.

\subsection{Collocators and semantic preferences}

Corpus data reveal the attractions between the word and its typical environments. The masculine/feminine pairs of nouns below present the most frequent combinations, with special reference to semantic fields and semantic preferences.

The English data are as follows.

I Actress/actor (1,259/3,600 hits in BNC): Using the BNC corpus and the Word Sketch function in Sketch Engine, it can be observed that some of the most frequent premodifiers of the feminine form are best, actor, bitpart, out-of-work, sought-after and singing. The word also co-occurs with nouns such as actor, singer, and dancer, and is often accompanied by names of well-known individuals (Hepburn). Among the verbs appearing in 
its proximity are also star, marry, support, win, lead, watch and become. The masculine form actor, on the other hand, is frequently premodified by words such as character, best, Hollywood, talented, comedy and unemployed; furthermore, it can be followed by, for instance, actress, singer, musician, and award; and it also co-occurs with the names of individuals (Branagh). The verbs that co-occur with the masculine form include vote, lead, dress, become, name, concern, play and portray. A comparison of the most frequent combinations in EnTenTen13 (via Sketch Engine, with a span of $+/-5$ words) shows that the feminine form is noticeably more frequently combined with the modifiers porn and supporting.

Considering the semantic preferences, both forms combine with expressions describing related professions; place names related to the profession; names of individuals; expressions describing the type/quality of work; activities related to the profession; and expressions related to awards. Some specific connotations of the feminine form are brought to the fore by the collocators such as aspiring, supporting, porn, affair and steamy; some of these may also appear with the masculine form, but less frequently.

II Policewoman/policeman (228/3,193 hits in BNC): The nouns policewoman/policeman have been largely replaced by the gender-neutral police officer; nevertheless, the data from BNC reveal some interesting differences between them. The feminine form appears after the premodifers like zoggian, plain-clothed, unlucky, probationer, off-duty and daredevil. The word is often followed by nouns such as baillet, teleanou, field-worker and firewoman; it also appears in the proximity of words like radio, rape, gun, fancy, staff and retreat. The most frequent collocators (based on the $\log$ Dice value) of the feminine form are also unluckiest, smartly and brave, which do not appear next to the masculine form. The masculine form policeman often co-occurs with off-duty, neighbourhood, plain-clothes, sleeping, secret and ordinary; it is used with verbs such as injure, assault, kill, patrol, arrest and kick; and it co-occurs with nouns that frequently include civilian, soldier, woman, fireman, detective and policewoman.

Regarding semantic preferences, both forms appear with expressions that refer to police activities or describe individuals connected to police work. The feminine noun is more frequently found next to personal names, in sci-fi contexts, and with adjectives that point to (positive) personal traits (smartly, brave). The observed word rape refers to an attempted rape of a female police officer. 
III Waitress/waiter (361/932 hits in BNC): The feminine form waitress is often premodified by cocktail, 17-year-old, assistant, Russian, head, young and good. It co-occurs with nouns such as job, service, waiter, chambermaid and cleaner, and verbs like call, ask, bring, be, serve and arrive. Among the frequent collocators are also the words Hooters, topless and flirt (logDice: 6.6, 5.8 and 5.3 respectively). The masculine noun appears with the premodifiers tide, obsequious, white-jacketed, head, dumb and wine. Waiter also co-occurs with waitress, attendant, chef, barman, maid and mеnu. It can also be found next to beckon, hover, summon, bow, serve, bring, pour and similar verbs.

With respect to semantic preferences, the pair waitress/waiter attracts collocators referring to related professions, typical activities, workplace objects, and expressions related to the activities of customers. Both also frequently co-occur with expressions related to appearance and character in which waitresses are more frequently positively perceived (attentive), and waiters negatively $(d u m b)$. The feminine noun also co-occurs with expressions that sexualize the profession (topless).

Moving to the Slovenian data, the feminine nouns can be divided into two main groups: Group A consists of those feminine nouns that do not differ from the masculine ones and are stylistically unmarked, whereas Group B includes those whose meaning is specialized or at least partly stylistically marked. The authors see these groups as extreme ends of a continuum, which is supported by examples that exhibit the features of both groups.

Representing Group A are the masculine/feminine pairs: zdravnica/zdravnik ('a female/male doctor'), sodnica/sodnik ('a female/male judge'), and vzgojiteljica/vzgojitelj ('a female/male kindergarden teacher'). Group B includes the pairs administratorka/administrator ('a female/male administrator'), tajnica/tajnik ('a female/male secretary'), kuharica/kuhar ('a female/male cook'), maserka/maser ('a female/male masseuse/masseur'), and čistilka/čistilec ('a female/male cleaner'). The selection of examples aims to present both prototypical and borderline examples in each group.

\section{Group A (semantically equivalent, stylistically unmarked forms):}

A-I Zdravnica/zdravnik ('female/male doctor'; 7,857/127,248 hits in FidaPLUS v2): ${ }^{7}$ The most frequent collocators of the feminine noun (logDice above 7, span +/-5 words) are dežurna ('on-call'), specialistka

\footnotetext{
${ }^{7}$ The number of hits stated here differs slightly from the one in Table 4; this is due to the subcorpora not containing all the data from FidaPLUS v2.
} 
('specialist'), pregledala ('examined'), medicine and Quinn - the results are slightly skewed here because of the series Dr. Quinn, Medicine Woman appearing in the numerous TV listings included in the corpus. The function Word Sketch, on the other hand, lists collocators that include the adjectives dežurna ('on-call'), oddelčna ('departmental'), cenjena ('highly valued'), zavodska ('institutional'); nouns such as znanstvenica ('a scientist'), pravnica ('a jurist'), upraviteljica ('a manager'), pedagoginja ('a pedagogue'); and verbs like oskrbeti ('treat'), predpisati ('prescribe'), prihiteti ('hurry'), odrediti ('order'), and pregledati ('examine'). The masculine form co-occurs with the adjectives dežurni ('on-call'), splošni ('general'), izbrani ('chosen'), hribovski ('mountain'), družinski ('family'); nouns like zobozdravnik ('a dentist'), bolnik ('a patient'), sestra ('a nurse'), zdravnica ('a doctor'); and verbs that include predpisati ('prescribe'), svetovati ('advise'), priporočati ('recommend'), pregledati ('examine'), and oskrbeti ('treat'). Some of the most frequent co-occurring expressions ( $\log$ Dice above 7 , span +/-5 words) are pojdite ('go'), predpiše ('prescribe'), dežurni ('on-call'), zaupajo ('trust'), splošni ('general'), bolniki ('patients'), sestre ('nurses').

The semantic preference for both forms is as follows: adjectives for the type of work done by doctors; verbs describing decisions related to medical treatment; and related professions.

A-II Sodnica/sodnik ('female/male judge'; 11,946/115,838 hits in FidaPLUS v2): The feminine noun frequently (logDice above 7 , span $+/-5$ words) appears in TV listings, which is evidenced by the frequent collocator raztresena ('absent-minded'), a word used in the Slovenian title of the series Ally McBeal. Similarly troublesome for the analysis are those hits referring to the series Judge Judy and Judging Amy, since the Slovenian translations of their titles include the word sodnica ('female judge'). More insight can be gained by examining the Word Sketch data. The frequent modifiers of the feminine noun include preiskovalna ('investigative'), okrajna ('county'), razpravljajoča ('hearing'), and dežurna ('on-call'). Female judges preside (predsedovati), order (odrediti), judge (razsoditi), grant (ugoditi), and interrogate (zaslišati). The feminine noun also appears next to nouns such as odločitev ('decision'), vprašanje ('question'), nepristranskost ('impartiality'), tožnica ('claimant'), odvetnica ('lawyer'), and pravnica ('jurist'). Some of the frequent collocators also include words related to sports: strelska ('shooting'), trenerka ('coach'), turnir ('tournament'). The findings are very similar when it comes to the masculine form: ustavni ('constitutional'), predsedovati ('preside'), 
izvolitev ('election'), porota ('jury'), nogometni ('football'), tekma ('match'), etc.

Both masculine and feminine forms appear in contexts related to law and sports. The semantic preferences are as follows: the position within the profession; activities related to decision-making; and related professions. A comparison of adjectives premodifying the two forms reveals a significant difference: the adjectives denoting important roles within the profession are more frequently found next to the masculine form: ustavni ('[masculine] constitutional') - 11,042 hits / ustavna ('[feminine] constitutional') - 442 hits; vrhovni ('[masculine] supreme') - 2781 hits / vrhovna ('[female] supreme') - 253 hits; okrajni ('[male] county') - 491 hits / okrajna ('[feminine] county') - 654 hits. The finding is relevant from the point of view of associative meaning and extra-linguistic circumstances, which may also explain the attraction of female judges (and doctors) for TV produces/audiences.

A-III Vzgojiteljica/vzgojitelj ('female/male kindergarten teacher'; 6,535/4,965 hits in FidaPLUS v2): The word vzgojiteljica often co-occurs ( $\log$ Dice above 7 , span +/-5 words) with the following collocators: vrtec ('kindergarten'), učiteljice ('teachers'), pomočnice ('assistants'), predšolski ('pre-school'), mentorica ('mentor'), otroci ('children'), opravili ('done'), poskrbele ('made sure'), etc. Word Sketch lists the typical adjectival promodifiers such as predšolska ('pre-school'), prizadevna ('dedicated'), diplomirana ('graduate'), usposobljena ('qualified'), zaposlena ('employed'), upokojena ('retired'); some of the verbal collocators are poučevati ('teach'), uresničiti ('realize'), razložiti ('explain'), spodbujati ('encourage'), skrbeti ('care'), zaposliti ('employ'), ustvarjati ('create'), načrtovati ('plan'); while the nominal collocators include učiteljica ('teacher'), vzgojitelj ('kindergarten teacher'), pomočnica ('assistant'), varuhinja ('guardian'), ravnateljica ('principal'), starš ('parent') and others.

The masculine noun frequently appears with učitelji ('teachers'), predšolskih ('pre-school'), otrok ('children'), vzgojiteljice ('kindergarten teachers'), starši ('parents'), vrtci ('kindergartens'), pedagogi ('pedagogues'), etc. Other collocators include dijaški dom ('student dormitory'), skrbnik ('guardian'), gojenci ('boarders'). The hits thus reveal a strong link between the masculine noun and secondary-school dormitories and similar institutions, which is confirmed in Word Sketch that lists adjectives like usposobljeni ('qualified'), pozorni ('attentive'), dežurni ('oncall'), strog ('strict'), zasebni ('private'); verbs such as pretepsti ('beat'), vzgajati ('raise'), spodbujati ('encourage'), poučevati ('teach'), skrbeti ('care'), spraševati ('ask'); and nouns like vzgojiteljica ('kindergarten 
teacher'), učitelj ('teacher'), katehet ('catechist'), starš ('parent'), gojenec ('boarder'), skrbnik ('guardian'), šolnik ('educator'), etc.

The described corpus data do not reveal any substantial differences between the masculine and feminine nouns: both are similarly frequent and appear with similar collocators. The semantic preferences can be described as: relating to work environment; people in related professions; and activities typical for the profession. Both forms also co-occur with similar expressions that describe an individual's character and their professional qualifications. Nevertheless, the data suggests that some elements of gender stereotyping may be present: for instance, female kindergarten teachers are dedicated, while male ones are strict. A similar finding can be associated with the working environment of student dormitories, where the masculine form is more common.

\section{Group B (narrower semantic meaning, partial stylistic marking):}

B-I Administrator/administrator ('female/male administrator'; 345/2,876 hits in FidaPLUS v2): The SSKJ ${ }^{2}$ defines the feminine form as "a lower office worker" and as "a woman who administers webpages". The masculine form is defined as "one who manages, a manager"; the same definition includes the use of the word in the field of information technology ("one who manages a computer system or an online forum") and, as the last option, the meaning of "a lower office worker". The staterun Employment Service of Slovenia only lists office-related positions in connection with this job title.

The corpus data (via Word Sketch) reveal that the feminine noun appears next to adjectives such as notarjeva ('notary's'), nezaposlena ('unemployed'), policistova ('policeman's'), radodarna ('generous'), ljubezniva ('kind'), vestna ('conscientious'), and postavna ('shapely'); verbs like pridirjati ('come running'), ožigosati ('stamp'), and prepisovati ('copy'); and nouns that include pisanje ('writing'), strežnica ('hospital attendant'), računovodkinja ('accountant') and menedžerka ('manager'). The masculine form is found next to adjectives such as apostolski ('apostolic'), sistemski ('systemic'), mrežni ('network'), dekanijski ('deanery's'), kolonialni ('colonial') and sposobni ('competent'); verbs like pregledovati ('check'), dodeljevati ('assign'), upravljati ('manage') and vzdrževati ('maintain'); and nouns such as forum ('forum'), špica ('peak'), strežnik ('computer server'), povezava ('connection'), baza ('database'), moderator ('moderator'), teoretik ('theoretician') and programmer ('programmer'). The typical collocators (logDice above 7, span +/-5 words) show that the most frequent ones involve expressions related to IT, for instance names, nicknames and other expressions common for online 
content: moderator ('moderator'), pridružen ('joined'), timi666 (a nickname), sistemski ('system'), sporočilo ('message'), etc.

The semantic preference of the feminine form can be identified in its cooccurrence with professions denoting superior positions; (gentle) character traits; appearance; office-related activities and locations. The masculine form collocators confirm its semantic preference for management positions, expressions describing high professional qualifications, and administration in the field of IT.

B-II Tajnica/tajnik ('female/male secretary'; 11,016/12,931 in FidaPLUS v2): The $\mathrm{SSKJ}^{2}$ defines the feminine form as "one who conducts administrative, organizational and technical business". The definition of the masculine form is identical, but it also includes the additional meaning of "a high official of some organization, body". The corpus-based analysis reveals, however, that the feminine form often combines with glavna ('main/head') in the sense of "high official". Despite this, the classification of occupations provided by the Employment Service of Slovenia lists the feminine form only in connection with its narrower meaning, and even states that the position is more commonly filled by women.

The frequent collocators for tajnica (Word Sketch) are telefonska/avtomatska ('phone/automatic') - referring to an answering machine - direktorjeva ('director's'), ministrove ('minister's'), županova ('mayor's'), Clintonova ('Clinton's') and similar. The word combines with verbs such as prevezati ('transfer calls'), se oglašati ('answer'), povedati ('tell'), vstopiti ('enter'), obveščati ('inform'), poklicati ('call'), and z njimi varati ('cheat with them'). It stands in proximity to nouns like izpopolnjevanje ('training'), klub ('club'), kongres ('congress'), stol ('chair'), pisarna ('office'), fikus ('ficus'), računovodkinja ('accountant'), blagajničarka ('treasurer'), receptorka ('receptionist'), snažilka ('cleaner'), ljubica ('lover'), razmerje ('affair'), etc. Corpus hits include sentences describing a diplomat who obtained an office, a ficus plant and a secretary, or bankers who are afraid to lose their armchairs, substantial salaries, secretaries and ficus plants.

The most frequent collocators of the masculine form (logDice above 7 , span $+/-5$ words) are prominent functions in organizations or names of individuals occupying these positions: glavni ('head/main'), sindikata ('union's'), sinode ('synod's') and demokratov ('Democrats"). According to Word Sketch, the form tajnik is often close to adjectives such as glavni ('main'), vatikanski ('Vatican'), generalni ('general'), and papeški ('papal'). The typical verbs in the proximity of the masculine form are službovati ('serve'), povedati ('tell'), pojasniti ('explain'), zatrditi 
('assure'), and nagovoriti ('address'). The masculine form also appears near nouns like blagajnik ('treasurer'), podtajnik ('deputy secretary'), podžupan ('deputy mayor'), računovodja ('accountant'), knjižničar ('librarian'), as well as near names of well-known personalities.

Regarding semantic preference, we can conclude that the feminine form is frequently linked to the business space led by an influential male (director) and surrounded by objects typical for such a space (office plants). In addition, the activities that tajnica is involved in are related to the flow of information and involve other professions below the managerial level. The examples clearly reflect the associative meaning of the feminine noun (a secretary is objectified by being equated with furniture and office plants). Some additional connotations can be identified in contexts related to socially less desirable interactions (affairs). On the other hand, the masculine form is mostly connected with the position of a high official. It co-occurs with important institutions, activities that involve addressing larger groups of people, and related professions.

B-III Kuharica/kuhar ('female/male cook'; 3,907/14,892 hits in FidaPLUS v2): The form kuharica is polysemous - besides the frequent meaning of "a woman who is (professionally) occupied with cooking", the meaning of "cookbook" is also common (see the $\mathrm{SSKJ}^{2}$ ). The masculine form is defined as "one who is (professionally) occupied with cooking".

The list of collocators for kuharica (logDice above 7, span +/-5 words) includes words such as Kalinšek (a well-known cook-book author), zaposlimo ('[we] employ'), Felicita (a well-known cook-book author), kuharji ('cooks'), natakarica ('waitress'), izvrstna ('excellent'), Vendelina (a well-known cook-book author), čistilka ('a cleaning lady'), odlična ('excellent'), recepti ('recipes'), and sobarica ('a chambermaid'). The function Word Sketch lists adjectives like farovška ('parochial'), ravnateljeva ('principal's'), izvrstna ('excellent'), žlehtna ('wicked'), izučena ('educated'), župnikova ('priest's'), vedoželjna ('eager to learn'), and pozabljiva ('forgetful'). The feminine noun is often coordinated with the nouns čistilka ('a cleaning lady'), kuhar ('a cook'), natakarica ('a waitress'), sobarica ('a chambermaid'), and hišnik ('a caretaker'). Some examples of the most frequent words that co-occur with the feminine noun are menza ('canteen'), gostilna ('inn'), kuhinja ('kitchen'), vrtec ('kindergarten'), dom ('home'), recept ('recipe'), praksa ('practice'), izkušnja ('an experience'), and družina ('family'). Among the verbal collocators the following can be observed: peči ('bake'), kuhati ('cook'), zaposliti ('employ'), obleči ('wear'), and upokojiti ('retire'). 
The masculine noun co-occurs with vaja ('an exercise'), natakar ('a waiter'), gospa ('Ms.'), hiša ('house'), nedoločen ('permanent'), najboljši ('the best'), dragocenosti ('valuables'), and poročila ('reports'). Word Sketch lists the following premodifying collocators: pojoč ('singing'), ljubiteljski ('amateur'), ladijski ('ship's'), izvrsten ('excellent'), dvoren ('court'), izučen ('trained'), pozabljiv ('forgetful'), and vešč ('skilful'). Kuhar often stands close to the nouns like natakar ('a waiter'), kuharica ('a cook'), slaščičar ('a confectioner'), jedec ('an eater'), gurman ('a gourmet'), menza ('a canteen'), restavracija ('a restaurant'), kuhinja ('a kitchen'), hotel ('a hotel'), gostilna ('an inn'), pomočnik ('a helper'), kapa ('a hat'), sekcija ('a section'), ekipa ('a team'), tekmovanje ('a competition'), and tečaj ('a course'). The verbs frequently found next to kuhar are servirati ('serve'), izmišljati ('make up'), speči ('bake'), skuhati ('cook'), odrezati ('cut off'), izobraževati ('educate'), postreči ('serve'), razjariti ('enrage'), najeti ('hire'), pripravljati ('prepare'), pokvariti ('spoil'), zaposliti ('employ'), and pohvaliti ('praise').

The semantic preferences for both nouns include expressions for related professions; character traits; professional qualifications; types of work; work environments; and activities related to the occupation. The analysis also reveals several socially constructed differences. The feminine noun is present in some specific work environments reserved for female cooks (parish house), and it appears with professions that typically require lower qualifications (cleaner). The masculine form, on the other hand, can refer to a ship's cook; it is more frequently described positively (excellent, trained); and is often associated with competitions (section, team, competition).

B-IV Maserka/maser (masseuse/masseur; 512/1,216 hits in FidaPLUS v2): The SSKJ ${ }^{2}$ uses the same definition for both forms: "a woman/one who professionally massages". Word Sketch lists some frequent premodifiers such as tajska ('Thai'), spretna ('skilful'), izurjena ('trained'), prikupna ('cute'), diplomirana ('graduate'); verbs zmasirati ('massage'), obdelovati ('do'); and nouns maser ('a masseur'), aromaterapevtka ('an aromatherapist'), fizioterapevtka ('a physiotherapist'), psihologinja ('a psychologist'), serviser ('a repairman'), sestra ('a nurse'), roka ('a hand'), etc. The corpus also includes the names of well-known sports masseuses. Some less frequent collocators ( $\log$ Dice under 7 , span $+/-5$ words) of the feminine noun include erotična ('erotic'), nežna ('gentle'), čarobna ('magic'), oblečena ('dressed'), and ljubezen ('love'). The data for the masculine form are very different. According to Word Sketch, a masseur is tajski ('Thai'), izšolan ('educated'), izurjen ('skilled'), izkušen ('experienced), usposobljen ('trained'), ukrajinski ('Ukrainian'), 
profesionalen ('professional'), and priznan ('renowned'), but not prikupen ('cute'). The most frequent verbs next to maser include pregnete ('knead'), gladi ('stroke'), masira ('massage'); it co-occurs with the nouns like pediker ('a pedicurist'), fizioterapevt ('a physiotherapist'), mehanik ('a mechanic'), kozmetičarka ('a beautician'), serviser ('a repairman'), psiholog ('a psychologist'), zdravnik ('a doctor'), and trener ('a coach'). The most frequent hits do not include the adjective erotični ('erotic'). In addition, the masculine noun is more prevalent in the fields of sport and medicine.

The semantic preferences shared by both the masculine and feminine nouns can be identified in expressions related to professional qualifications; typical activities; and similar professions. The differences can be detected in the words describing personal traits and appearance (cute), as well as in corpus hits involving erotic massages - such collocators co-occur with the feminine form and testify to the often perceived sexualization of the profession.

B-V Čistilka/čistilec ('female/male cleaner'; 1,950/1,767 hits in FidaPLUS v2): Word Sketch lists the feminine form with adjectives such as optimistična ('optimistic'), pridna ('hard-working'), bosanska ('Bosnian'), priljubljena ('popular'), mlada ('young'); verbs like pospravljati ('tidy up'), zboleti ('fall ill'), preživljati ('support'), pobirati ('pick up'), čistiti ('clean'), zaposliti ('employ'); nouns as čistilec ('a cleaner'), kuharica ('a cook'), vrtnarka ('a gardener'), zaposlitev (employment), plača ('a salary'), and čiščenje (cleaning). The most frequent collocators (logDice above 7 , span +/-5 words) include words like Fata (a female Bosnian name), sobarica ('a chambermaid'), and hišnik ('a caretaker'). The masculine noun most frequently stands next to words that suggest that it refers to cleaning appliances: visokotlačni ('high-pressure'), kemični ('chemical'), parni ('steam'), vakuumski ('vacuum'), etc. Only a few collocators refer to people, e.g. a sentence in the corpus states that a shop is "meant for professional and amateur [male] cleaners, as well as housewives". The cooccurring verbs are izobraževati ('educate'), čistiti ('clean'), zaposliti ('employ'), while the nouns include smetar ('a garbage collector'), vzdrževalec ('a maintenance worker'), čistilnica ('a laundry shop'), kuhar ('a cook'), natakar ('a waiter'), traktor ('a tractor'), and prah (dust).

Considering the semantic preference, we can conclude that it encompasses words referring to character traits; typical activities related to cleaning; and similar professions that require lower qualifications. The associative meaning of the feminine noun can be observed in the hits that involve the collocators bosanska (Bosnian) and Fata (a stereotypical female 
Bosnian name). The masculine form mostly refers to appliances, signalling that the profession of a cleaner is mostly perceived as a female one.

\section{Discussion}

The first part of the paper is focused on the derivation of feminine and masculine nouns for professions in English and Slovenian. The analysis shows that the dominant form of feminine nouns in both languages involves derivation via affixation, while English also features compounding. Masculinatives are rare in both languages; they are mostly formed in relation to professions which have been traditionally considered part of the female sphere. Besides the masculine suffix $-e c$, which was previously discussed by Vidovič-Muha (2018:410), the analysis also identifies the Slovenian masculine suffix -ar. The suffix is not productive but can nevertheless be observed in the word babičar ('male midwife'). The most notable difference between the two languages is that contemporary English seems to be abandoning the use of gender-marked forms (except for the rare feminatives that remain), whereas in Slovenian, as evidenced by corpus data, the use of feminatives is on the rise. The reason for this asymmetry is rooted in the fact that English has an almost non-existent grammatical gender system, and in most cases uses the same words to describe a man or woman working in a certain profession. In contrast, Slovenian grammatical gender is fully grammaticalized and may or may not overlap with biological sex. Slovenian nouns denoting professions have clear referents with regard to gender, and their contemporary use - evidenced in corpora - shows a clear tendency towards the agreement between grammatical and biological genders. Thus, in the case of female referents the use of feminine nouns is now preferred, while the use of masculine generic forms is on the decline.

Our corpus analysis shows that the differences between masculine and feminine nouns for professions are best revealed by examining their collocators, semantic preferences, and semantic associations (Sinclair 1996 and Philip 2010).

The collocators of English masculine and feminine nouns for the examined professions (actress/actor, policewoman/policeman in waitress/waiter) reveals that they share some semantic environments: related professions; places and surroundings associated with the profession; personal names; words describing the quality of their work; and the typical actions associated with the profession. Some specific associative meanings are also revealed if we examine the collocators describing human traits and appearance. The feminatives often co-occur with expressions for stereotypically female character traits and personality (including sexual 
connotations). This is in line with Caldas-Coulthard and Moon (2010), who explain such asymmetries with stereotypes of gender, sexualization of women, as well as with age and behaviour.

Slovenian masculine/feminine pairs for professions reveal similar findings. Regarding semantic preference, we can observe expressions related to typical actions; typical places and surroundings; related professions; character traits; and appearance. Yet the corpus data also show some significant differences. The pairs of Slovenian masculine and feminine nouns referring to professions can be divided into two groups. The first one comprises pairs that are semantically equivalent and stylistically unmarked (see Derganc, 2017), while the pairs in the second group are subject to (a degree of) semantic narrowing and stylistic marking.

A prototype for the first group is the pair zdravnicalzdravnik ('female/male doctor'), both of which can co-occur with expressions referring to the type of work, typical actions and related professions. The feminine nouns in such pairs are stylistically unmarked. A similar conclusion can be reached for the pairs sodnica/sodnik ('female/male judge') and vzgojiteljica/vzgojitelj ('female/male kindergarten teacher'), but with a caveat. The form of the pair sodnica/sodnik overlap in the fields of law and sport; however, the data also reflect the societal status of the profession - the most important positions (e.g., constitutional judges) are still mostly reserved for men. The pair vzgojiteljica/vzgojitelj can be described as a borderline case between marked and unmarked meaning. The corpus data suggest a degree of semantic narrowing and stylistic marking: the meaning of "teacher in a student dormitory" refers to men, while the use of adjectives (diligent women and strict males) points to gender stereotyping.

Partially marked forms that also involve semantic narrowing have been presented using the pairs administatorka/administrator ('female/male administrator'), tajnicaltajnik ('female/male secretary'), kuharicalkuhar ('female/male cook'), maserka/maser ('masseuse/masseur'), and čistilka/čistilec ('female/male cleaner'). The masculine nouns administrator and tajnik are associated with socially more prominent professions, which is confirmed by the definitions in the $\mathrm{SSKJ}^{2}$. Administratorka tends to be in a subordinate position (notary), and is often described as shapely (appearance) or kind (character). A similar conclusion can be reached for tajnica, which co-occurs with expressions signalling her objectification (ficus plant) and sexualization (affair). Socially-constructed differences have been identified for the pair kuharicalkuhar as well. The feminine noun appears in specific work environments (parsonage) and with professions that require lower qualifications, while the masculine noun appears in 
contexts related to competitions. Still, in this case, the meaning is not narrow enough to justify, for instance, separate dictionary definitions. The same can be concluded for the pair maserka/maser, which demonstrates, again, that feminatives are more likely to appear with expressions describing appearance (cute) and sexual activities (erotic). The final pair cistilkalčistilec - shows that the profession is often associated with a specific ethnic group (Bosnian) and with stereotypes about this group (the name Fata). It can be also observed that this is a profession dominated by women, since the masculine form is mostly used to describe appliances.

\section{Conclusion}

The contrastive corpus analysis of collocators in English and Slovenian presented in this paper has shown that in both languages there are cases in which the feminine nouns can be described as stylistically unmarked. However, the study has identified numerous cases of masculine and feminine nouns for professions occurring in contexts that reflect the status of their referents in society. Due to these extra-linguistic factors, feminine nouns are more frequently accompanied by stereotypical views of gender roles, appearance and character: thus, their female referents are often sexualized and objectified. The masculine nouns, on the other hand, typically highlight the important position of their referents.

In the end, it should be pointed out that the main focus of the paper has been a synchronic analysis of the subject matter, relying on corpora that mostly contain examples from written language. Considering these limitations, we hope that our findings will motivate future research on the use of masculine and feminine nouns also from a diachronic perspective as well as from the point of view of different text-types.

\section{Corpora and Tools}

SSKJ2: Dictionary of Standard Slovenian, www.fran.si.

BNC: https://old.sketchengine.co.uk/.

EnTenTen13: https://old.sketchengine.co.uk/.

FidaPLUS v2: https://old.sketchengine.co.uk/.

SketchEngine, 2018: https://www.sketchengine.eu/. 


\section{References}

Bartsch, Sabine. (2004). Structural and functional properties of collocations in English: a corpus study of lexical and pragmatic constraints on lexical cooccurrence. Tübingen: Gunter Narr.

Bauer, Laurie. (1996). English Word-formation. Cambridge: Cambridge University Press.

Caldas-Coulthard, Carmen Rosa, Moon, Rosamund. (2010). Curvy, hunky, kinky: Using corpora as tools for critical analysis. In Discourse \& Society No 21/2. 99133. https://doi.org/10.1177/0957926509353843.

Crowther, Jonathan, Dignen, Sheila, Lea, Diana (Ed.). (2002). Oxford Collocations Dictionary for Students of English. Oxford: Oxford University Press.

Derganc, Aleksandra. (2017). Poimenovanje za ženske nosilke poklicev in položajev $\mathrm{v}$ slovenščini in ruščini [Naming for women holders of professions and positions in Slovenian and Russian]. In Jezikoslovni zapiski [Linguistic notes] No 23/2. 125-130. https://doi.org/10.3986/JZ.23.2.6906.

Gablasova, Dana, Brezina, Vaclav, McEnery, Tony. (2017). Collocations in corpusbased language learning research: identifying, comparing, and interpreting the evidence. In Language Learning No 67/S1. 155-179. https://doi.org/10.1111/lang.12225.

Gabrovšek, Dušan. (2014). Extending binary collocations: (lexicographical) implications of going beyond the prototypical a - b. In ELOPE: English language overseas perspectives and enquiries No 11/2. 8-20. https://doi.org/10.4312/elope.11.2.7-20.

Gabrovšek, Dušan. (2005). Words Galore: Aspects of general and Slovenian-English contrastive lexicology. Ljubljana: FF UL, Oddelek za anglistiko in amerikanistiko.

Hoey, Michael. (2005). Lexical Priming: A New Theory of Words and Language. London: Routledge.

Holmes, Janet. (2001). A corpus-based view of gender in New Zealand. In Gender Across Languages: The linguistic representation of women and men. Marlis Hellinger and Hadumod Bussman, ed. Amsterdam: John Benjamins. 115-136.

Huddleston, Rodney, Pullum, Geoffrey K. (2002). The Cambridge Grammar of the English Language. Cambridge: Cambridge University Press.

Jurko, Primož. (2015). Evaluative Meaning in Translation. In ELOPE: English language overseas perspectives and enquiries No 12/2. 193-209. https://doi.org/10.4312/elope.12.2.193-209.

Kilgarriff, Adam. Baisa, Vít. Bušta, Jan. Jakubíček, Miloš. Kovář, Vojtěch. Michelfeit, Jan. Rychlý, Pavel. Suchomel. Vít. (2014). The Sketch Engine: ten years on. In Lexicography No 1/1. 7-36. https://doi.org/10.1007/s406070140009-9.

Kranjc, Simona, Ožbot, Martina. (2013). Vloga spolno občutljivega jezika v slovenščini, angleščini in italijanščini [The role of gender sensitive language in Slovenian, English and Italian]. In Družbena funkcijskost jezika: vidiki, merila, opredelitve (Obdobja 32) [Social Functionality of Language: Aspects, Criteria, 
Definitions]. Andreja Žele (ed.). Ljubljana: Znanstvena založba Filozofske fakultete. 233-239.

McIntyre, Dan. (2018). Irony and semantic prosody revisited. In The Pragmatics of Irony and Banter. Manuel Jobert and Sandrine Sorlin (eds.). Amsterdam: John Benjamins. 81-99.

Philip, Gill E. (2010). Why prosodies aren't always present: Insights into the idiom principle. In Proceedings of the Copus Lingusitics Conference CL2009. Michaela Mahlberg, Victorina González-Díaz and Catherine Smith. Liverpool: University of Liverpool. URL: http://ucrel.lancs.ac.uk/publications/cl2009/.

Quirk, Randolph et al. (1999). A Comprehensive Grammar of English. Harlow: Longman.

Rychlý, Pavel. (2008). A lexicographer-friendly association score. In Proceedings of Recent Advances in Slavonic Natural Language Processing, RASLAN. Petr Sojka and Aleš Horák, ed. Brno: Masaryk University. 6-9.

Sinclair, John. (1996). The search for units of meaning. In Textus: English Studies in Italy No 9. 75-106.

Stubbs, Michael. (2001). Words and Phrases. Corpus Studies of Lexical Semantics. Oxford: Blackwell.

Stubbs, Michael. (2007). Quantative data on multi-word sequences in English: The case of the word world. In Text, Discourse and Corpora: Theory and Analysis. Michael Hoey, Michaela Mahlberg, Wolfgang Teubert and Michael Stubbs, eds. London: Continuum. 163-189.

Šrli, Mojca. (2013). Corpus-based lexicographical descriptions with a special focus on pragmatics: the case of the Slovene lexical database. In ELOPE: English language overseas perspectives and enquiries No 10/2. 45-65. https://doi.org/10.4312/elope.10.2.45-65.

Šrli, Mojca. (2012). Semantična prozodija v teoriji in praksi - korpusni pristop $k$ proučevanju pragmatičnega pomena: primer slovenščine in angleščine [Semantic prosody in theory and practice - a corpus approach to the study of pragmatic meaning: Slovene and English]. In Dvojezična korpusna leksikografija: slovenščina v kontrastu: novi izzivi, novi obeti [Bilingual corpus lexicography: Contrasting Slovenian: New challenges, new outlook]. Mojca Šorli (ed.). Ljubljana: Trojina, zavod za uporabno slovenistiko. 90-116.

Štumberger, Saška. (2015). Veränderungen in der gesellschaftlichen Stellung von Frauen in Slowenien seit 1991: Personenbezeichnungen im Wörterbuch Slovar novejšega besedja slovenskega jezika (2012). In New Approaches to Gender and Queer Research in Slavonic Studies. Dennis Scheller-Boltz, ed. Wiesbaden: Harrasowitz. 101-109.

Toporišič, Jože. (2000). Slovenska slovnica [Slovenian grammar]. Maribor: Obzorja. Uhlik, Mladen. (2019). Izražanje spolske korelacije pri položajnih poimenovanjih v ruščini in slovenščini [Expressing gender correlation in positional denominations in Russian and Slovenian]. In Slavistična revija [Slavistic revue] 67/2. (In press).

Vidovič-Muha, Ada. (2018). Slovensko skladenjsko besedotvorje [Slovenian syntactic word formation]. Ljubljana: Filozofska fakulteta. 